\title{
Prospects for the development and use of a clay-nitrogen mixture as a fertilizer
}

\author{
Anastasiya Ruchkina ${ }^{1,}$, Roman Ushakov ${ }^{1}$, Natalya Golovina ${ }^{2}$, Victor Aseev ${ }^{3}$, and Fedor \\ Bobrakov $^{3}$ \\ ${ }^{1}$ FSBE HE RSATU, Kostychev Str., 390044, Ryazan, Russia \\ ${ }^{2}$ FSBE HE RyazSMU, Vysokovoltnaya Str., 9, Ryazan, Russia \\ ${ }^{3}$ FSBE HE RSU, 390000, Ryazan, Svoboda Str., 46, Ryazan, Russia
}

\begin{abstract}
The purpose of this work is to obtain and evaluate the fertilizing ability of the clay-nitrogen mixture. The relevance of the research lies in studying issues related to the minimization of nitrogen losses when producing the clay-nitrogen fertilizer, the transformation of nitrogen from fertilizer into the soil, and the effectiveness of fertilization when growing barley. The data on the content of nitrate nitrogen $(250,986$ $\mathrm{mg} / \mathrm{kg}$ ) and the total one (5.0\%) indicate the effective binding of nitric acid by clay. The fertilizer can be considered potassium-containing, since the content of mobile and total potassium is respectively $1,250 \mathrm{mg} / \mathrm{kg}$ and $0.20 \%$. Mobile phosphorus in the fertilizer is low compared to potassium $(76 \mathrm{mg} / \mathrm{kg})$, although the total pool is twice as large $(0.45 \%)$. The content of the gross form of copper $(8.9 \mathrm{mg} / \mathrm{kg})$ and zinc $(9.5 \mathrm{mg} / \mathrm{kg})$ corresponded to the MPC.
\end{abstract}

\section{Introduction}

The priority task of agriculture is to preserve and increase the resources of soil fertility. To a large extent, the manifestation of this property is associated with the soil-absorbing complex (SAC) and the content of nutrients [1].

One of the reasons for soil fertility deterioration is a decrease in the functional activity of the SAC due to the loss of substances with high sorption activity or high molecular weight organic compounds, fine mineral fractions. This is a prerequisite for soil degradation [1].

Experimental data of some scientists indicate the prospects of using natural clays as chemical ameliorants. They contribute to improvement of physical and chemical properties, reduce risks of the development of degradation processes [2].

Experimental data of some authors indicate the positive influence of various natural clays on the properties and productivity of agricultural plants $[3,4,5,6]$. This is especially important given the organic matter problem $[7,8]$.

Analysis of the literature indicates the promising nature of the use of natural clays in agriculture. In our opinion, it would be even more attractive when enriching clays with

\footnotetext{
* Corresponding author: uhanovamu@mail.ru
} 
nitrogen to improve soil properties and at the same time provide agricultural plants with this important element.

The technological difficulty of using nitric acid as a component when producing nitrogen fertilizers is its chemical aggressiveness. The use of ammonia as a neutralizer does not allow the production of a nitrogen fertilizer at the farm. It is proposed to use natural clay as an available feedstock to bind nitric acid nitrogen when producing a clay-nitrogen fertilizer (CNF).

The relevance of the research lies in studying issues related to the minimization of nitrogen losses when producing $\mathrm{CNF}$, the transformation of nitrogen from fertilizer into the soil and the effectiveness of fertilization when growing barley. The purpose of this work is to obtain and evaluate the fertilizing ability of CNF.

At the stage of obtaining the experimental CNF, the tasks of establishing the optimal mixing mode of components were solved to minimize the loss of nitrogen in nitric acid. The assessment of the fertilizing ability provided for the determination of the main chemical and physical-chemical characteristics of the fertilizer mixture, provided for the establishment of the mobility of the nitrate nitrogen of the fertilizer and the efficiency when growing barley.

\section{Materials and methods}

The clay in the experiments was preliminarily crushed to $5 \mathrm{~mm}$, mixed with nitric acid sprayed through nozzles until the clay was completely saturated in a special module. Lime was used as a neutralizer of weakly adsorbed nitric acid to reduce nitrogen losses $\left(\mathrm{CaCO}_{3}\right)$.

To obtain CNF, a red-colored natural clay was used, the chemical and granulometric composition of which is shown in Table 1.

Table 1. Chemical and granulometric composition of natural clay

\begin{tabular}{|c|c|c|c|c|c|c|c|c|c|c|}
\hline$\stackrel{N}{\infty}$ & 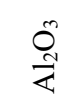 & $\overbrace{\mathbb{N}}^{\tilde{I}}$ & $\overbrace{\infty}^{\infty}$ & $\begin{array}{l}\underset{N}{v} \\
0\end{array}$ & $\bar{U}$ & O্ঠ & $\sum_{i}^{\infty}$ & $\stackrel{o}{\xi}$ & $\begin{array}{c}\text { Clay } \\
\text { particles, } \\
\%\end{array}$ & Silt, \% \\
\hline 52.7 & 18.9 & 9.6 & 0.17 & 5.1 & 0.18 & 1.3 & 2.9 & 0.01 & 44.2 & $\begin{array}{l}54.9 \\
\end{array}$ \\
\hline
\end{tabular}

When manufacturing equipment for the production of CNF, questions arise about the technological mode of mixing the components. This is due to:

1. The chemical aggressiveness of nitric acid (strong oxidant, active decomposition into water and nitrogen dioxide).

2. The general negative charge of clay particles, therefore, the impossibility of sorption of nitrate ions.

For this, two laboratory experiments took place.

To study the issue of minimizing nitrogen $\left(\mathrm{NO}_{2}\right)$ losses from decomposed nitric acid, laboratory experiment 1 with cooled and room $\mathrm{HNO}_{3}$ and laboratory experiment 2 with a drying temperature of more than $70^{\circ} \mathrm{C}$ and less than $70^{\circ} \mathrm{C}$ were carried out.

For a brighter visualization of the release of nitrogen dioxide in experiment 1 , five ironcontaining buttons were used, which were mixed with clay in Petri dishes and used separately from it. The decomposition intensity of nitric acid was determined by the characteristic brown gas.

1. $\mathrm{Fe}+\mathrm{HNO}_{3}(\mathrm{cool})$

Laboratory experiment scheme 1:

2. $\mathrm{Fe}+\mathrm{HNO}_{3}\left(\mathrm{t}+22^{\circ} \mathrm{C}\right)$

3. $\mathrm{Fe}+\mathrm{HNO}_{3}(\mathrm{cool})+$ clay

4. $\mathrm{Fe}+\mathrm{HNO}_{3}\left(\mathrm{t}+22^{\circ} \mathrm{C}\right)+$ clay

Laboratory experiment scheme 2 : 
1. Drying at $\mathrm{t}>70^{\circ} \mathrm{C}$

2. Drying at $\mathrm{t}<70^{\circ} \mathrm{C}$

To study the mobility of nitrate nitrogen of the mixture, laboratory experiment 3 was carried out. For this, fertilizers weighing 1 and $5 \mathrm{~g}$ were mixed with $40 \mathrm{ml}$ of distilled water and agitated for a minute. The suspended suspension was added to $80 \mathrm{~g}$ of soil. The following things were determined: the $\mathrm{pH}$ of the aqueous extract (GOST 26423), the $\mathrm{pH}$ of the salt extract (GOST 26483), hydrolytic acidity (GOST 26484), the mass fraction of total nitrogen (GOST 26107).

Laboratory experiment scheme 3 :

1. The ratio of the fertilizer to soil (1:80) is equivalent to a nitrogen dose of $62 \mathrm{~kg} / \mathrm{ha}$

2. The ratio of the fertilizer to soil (5:80) is equivalent to a nitrogen dose of $310 \mathrm{~kg} / \mathrm{ha}$

To determine the effectiveness of the fertilizer, a small-plot field experiment with barley on agro-gray loamy fine sandy coarse-dusty soil was laid in three replicates. The agrochemical characteristics are given in Table 2. The standards for the optimum humus content for agro-gray loamy light soil of the Central Russian province were set 2.3-3.0. The state of organic matter corresponded more likely to the minimum permissible level than to the optimal one in the experimental soil in a layer of $0-30 \mathrm{~cm}$ with an insignificant thickness of the humus horizon of $0-11 \mathrm{~cm}$ and a powerful humus-eluvial layer of up to 30 $\mathrm{cm}$. The supply of phosphorus and potassium was high. Given the dynamism of these indicators, they should not be considered informative in assessing the general condition of the soil. Here it is necessary to use structural and substantive characteristics. Along with the humus content, they include the granulometric composition. The content of physical clay increases by 2 times with depth. This indicates an intense eluvial process. Data on CEC and total nitrogen correspond to the diagnostic characteristics of agro-gray soil.

Table 2. Agrochemical characteristics of agro-gray loamy light soil

\begin{tabular}{|c|c|c|c|c|c|c|c|}
\hline $\begin{array}{c}\text { Layer, } \\
\mathrm{cm}\end{array}$ & $\begin{array}{c}\mathrm{K} 2 \mathrm{O}, \\
\mathrm{mg} / \mathrm{kg}\end{array}$ & $\begin{array}{c}\mathrm{P}_{2} \mathrm{O} 5, \\
\mathrm{mg} / \mathrm{kg}\end{array}$ & $\begin{array}{c}\text { Total } \\
\text { nitrogen, \% }\end{array}$ & $\begin{array}{c}\mathrm{pH}, \\
\mathrm{pH} \text { unit }\end{array}$ & $\begin{array}{c}\text { Organic } \\
\text { matter, \% }\end{array}$ & $\begin{array}{c}\text { CEC, mg } \\
\text { eq/100 g }\end{array}$ & $\begin{array}{c}<0.01, \\
\%\end{array}$ \\
\hline $0-20$ & $156.7 \pm 23.3$ & $211.3 \pm 42.3$ & 0.13 & $5.4 \pm 0.1$ & $2.3 \pm 0.5$ & 26.0 & 24.6 \\
\hline $20-30$ & $114.7 \pm 17.3$ & $171.3 \pm 34.3$ & 0.14 & $5.4 \pm 0.1$ & $1.9 \pm 0.5$ & 26.0 & 24.8 \\
\hline
\end{tabular}

In general, the fertility of the agro-gray soil can be regarded as unsatisfactory. This is primarily due to the low humus content and the resulting manifestations of negative processes, which can cover, as some sources show, the entire complex of soil properties.

The agricultural technology of barley cultivation was generally accepted for the southern part of the nonchernozem belt. The record plot was $10 \mathrm{~m}^{2}$. The yield was determined at standard grain moisture.

\section{Results and discussion}

Table 3 gives a brief description of the experimental fertilizer. One of its disadvantages is the slightly acidic reaction of the medium $\left(\mathrm{pH}_{\mathrm{KCl}}\right.$ about 5). The data on the content of nitrate nitrogen $(250,986 \mathrm{mg} / \mathrm{kg})$ and the total one $(5.0 \%)$ indicate the effective binding of nitric acid by clay. This fertilizer can be considered potassium-containing, since the content of mobile and total potassium is respectively $1,250 \mathrm{mg} / \mathrm{kg}$ and $0.20 \%$. Mobile phosphorus in the fertilizer is not high in comparison with potassium $(76 \mathrm{mg} / \mathrm{kg})$, although the total 
pool is twice as large $(0.45 \%)$. The content of the gross form of copper $(8.9 \mathrm{mg} / \mathrm{kg})$ and zinc $(9.5 \mathrm{mg} / \mathrm{kg})$ corresponded to the MPC.

Table 3. Chemical characteristics of CNF (average values)

\begin{tabular}{|c|c|c|c|}
\hline Indicator & Value & $\begin{array}{c}\text { Unit of } \\
\text { measurement }\end{array}$ & GOST \\
\hline Water & $9.5 \pm 0.5$ & $\%$ & GOST 20851.4 \\
\hline Reverse acidity & $5.3 \pm 0.4$ & unit & GOST 26483 \\
\hline Actual acidity & $7.3 \pm 0.7$ & unit & $\begin{array}{c}\text { Manual on Agrochemistry, } \\
\text { Mineev, V.G., 2001 }\end{array}$ \\
\hline Nitrate nitrogen & $250,986 \pm 30$ & $\mathrm{mg} / \mathrm{kg}$ & GOST 26951 \\
\hline Total nitrogen & $5.0 \pm 0.4$ & $\%$ & GOST 30181.4 \\
\hline Mobile potassium & $1,250 \pm 13$ & $\mathrm{mg} / \mathrm{kg}$ & GOST R 54650 \\
\hline Total potassium & $0.20 \pm 0.02$ & $\%$ & GOST 20851.3 \\
\hline Mobile phosphorus & $76.0 \pm 3$ & $\mathrm{mg} / \mathrm{kg}$ & GOST R 54650 \\
\hline Total phosphorus & $0.45 \pm 0.07$ & $\%$ & GOST 20851.2 \\
\hline Calcium & $128.68 \pm 2$ & $\mathrm{~mol} / 100 \mathrm{~g}$ & GOST 26487-85 \\
\hline Copper & $8.8 \pm 0.9$ & $\mathrm{mg} / \mathrm{kg}$ & GOST R 50684 \\
\hline Zinc & $9.5 \pm 0.9$ & $\mathrm{mg} / \mathrm{kg}$ & GOST R 50686 \\
\hline $\begin{array}{c}\text { Cation exchange capacity } \\
\text { (CEC) }\end{array}$ & $47.6 \pm 7.1$ & $\mathrm{mg} \mathrm{eq} / 100 \mathrm{~g}$ & GOST 17.4.4.01-84 (n. 4.1) \\
\hline
\end{tabular}

The use of a clay component has at least two goals: to fix nitrogen and to improve the surface properties of agro-gray soil. The CEC value of clay was $47.6 \mathrm{mg}$ eq/100 g. The diagnostic value for gray forest clay-and-sand and clay soils (according to the classification of 1977) was $20-25 \mathrm{mg}$ eq/100 g. CEC in the experimental soil was $26.0 \mathrm{mg}$ eq/100 $\mathrm{g}$ in the layers of $0-20$ and $20-30 \mathrm{~cm}$. Consequently, the regular introduction of clay matter will improve the sorption properties of the SAC.

Technologically, the use of nitric acid without preliminary neutralization is impossible due to its instability to light. It is suggested using it without additional costs for neutralization by pre-cooling it. The laboratory experiment has shown that the use of chilled nitric acid postpones the reaction of its interaction with iron. The release of nitrogen dioxide was not detected in variants 1 and 3. After 25-30 minutes, the temperature of the cooled nitric acid reached the room temperature and the process of release of the brown gas began in variant 1 . Variant 3 with clay did not have this effect and subsequently it was not observed. This suggests that in 25-30 minutes the clay, as a result of physical sorption of cooled nitric acid, transferred it into an inactive state, in which nitric acid did not decompose.

One of the stages of obtaining CNF is drying it immediately after mixing clay and nitric acid. To study the issue of nitrogen behavior at this technological stage, laboratory experiment 2 was carried out. It was found that with more gentle drying $\left(t<70^{\circ} \mathrm{C}\right)$, nitrogen losses decreased by $30 \%$ compared to drying at $\mathrm{t}>70^{\circ} \mathrm{C}$.

The fertilizing effect (availability) depends on mobility of the element. In this case, nitrogen mobility was established by determining nitrogen in the soil after adding a solution obtained as a result of the interaction of CNF with water (experiment 3 ).

Table 4. Nitrogen content and acidity of agro-gray soil

\begin{tabular}{|c|c|c|c|c|c|c|}
\hline Variant & $\begin{array}{c}\text { Total } \\
\text { nitrogen in } \\
\text { CNF, \% }\end{array}$ & $\begin{array}{c}\text { Initial total } \\
\text { nitrogen in soil, } \\
\%\end{array}$ & $\begin{array}{c}\text { Total } \\
\text { nitrogen, } \\
\%\end{array}$ & $\begin{array}{c}\mathrm{pH} \text { of } \\
\text { water } \\
\text { extract }\end{array}$ & $\begin{array}{c}\mathrm{pH} \text { of } \\
\text { salt } \\
\text { extract }\end{array}$ & $\begin{array}{c}\text { Hydrolytic } \\
\text { acidity, } \\
\text { mol/100 g }\end{array}$ \\
\hline $\begin{array}{c}\text { Equivalent } \\
\text { nitrogen dose of }\end{array}$ & 5 & 0.04 & 0.050 & 5.75 & 5.23 & 2.15 \\
\hline
\end{tabular}




\begin{tabular}{|c|c|c|c|c|c|c|}
\hline $62 \mathrm{~kg} / \mathrm{ha}$ & & & & & & \\
\hline $\begin{array}{c}\text { Equivalent } \\
\text { nitrogen dose of } \\
310 \mathrm{~kg} / \mathrm{ha}\end{array}$ & 5 & 0.04 & 0.095 & 6.10 & 6.10 & 1.69 \\
\hline
\end{tabular}

The experimental CNF was tested in the field in 2018 and 2019. The nitrogen dose was about $50 \mathrm{~kg} / \mathrm{ha}$. The fertilizer was applied in spring at the same time as sowing. The weather conditions were unfavorable for 2 years. Up to the tillering phase, precipitation was $30 \%$ of the norm.

The yield increase was about 5-7 dt/ha in comparison with the control (without fertilizers).

\section{Conclusion}

The use of clay and nitric acid to obtain a fertilizer at the farm with a simultaneous ameliorating effect is a promising measure. This can be understood from the laboratory results of the chemical composition in the fertilizer. Further research is necessary to clarify the issues of the influence of the clay component on the soil SAC, improve the technological properties of the clay-nitrogen fertilizer, its prospects and determine the place in the fertilizer system.

\section{References}

1. L.S. Travnikova, Organomineral interactions: the role in the formation processes, their fertility and resistance to degradation, Soil Institute Named after V.V. Dokuchaev of the Russian Agricultural Academy (Moscow, 2012)

2. T.A. Sokolova, Pedology, 2, 1-16 (2013)

3. A.V. Kozlov, A.Kh. Kulikova, I.P. Uromova, Bul. Soil. In-te Named after V.V. Dokuchaev, 90: 73-95 (2017)

4. E.V. Agafonov, A.V. Tsygankov, Farming, 7, 24-26 (2011)

5. E.V. Agafonov, V.P. Goryachev, Farming, 8, 20-21 (2011)

6. Z.A. Bolieva, F.T. Gerieva, Farming, 7, 17-18 (2012)

7. Jerry L. Hatfield, Ken Wacha, Christian Dold, Crops \& Soils, 51(2), 75-79 (2018)

8. A. Straathof, Crops \& Soils, 52(6), 129-133 (2019) 